\title{
Editorial \\ Cyclophosphamide in systemic sclerosis: still in search of a 'real life' scenario
}

\author{
Irene Miniati ${ }^{1}$, Gabriele Valentini ${ }^{2}$ and Marco Matucci Cerinic ${ }^{1}$
}

\begin{abstract}
1Department of Biomedicine, Division of Rheumatology AOUC, Denothe Center, University of Florence, Viale Pieraccini 18, 50139 Florence, Italy 2Department of Internal Medicine, Rheumatology Unit, Second University of Naples, Via Pacifici 5, 80131 Napoli, Italy
\end{abstract}

Corresponding author: Marco Matucci Cerinic, cerinic@unifi.it

Published: 23 January 2009

Arthritis Research \& Therapy 2009, 11:103 (doi:10.1186/ar2576)

This article is online at http://arthritis-research.com/content/11/1/103

(C) 2009 BioMed Central Ltd

See related research by Nannini et al., http://arthritis-research.com/content/10/5/R124

\begin{abstract}
In systemic sclerosis (SSc), there is no proven treatment to prevent disease progression. In a recent meta-analysis of three randomised controlled trials (RCTs) and six open prospective studies on cyclophosphamide (CYC), no significant changes in lung function were observed. However, CYC is associated with an improvement of Mahler's dyspnea index, short form-36 (physical and mental domains), and health-related quality of life, contributing to the amelioration of patients' functional status. Further RCTs on early SSc are needed to assess the real efficacy of CYC in inducing remission and increasing survival.
\end{abstract}

In a previous issue of Arthritis Research \& Therapy, Nannini and colleagues [1] addressed the topic by a well-conducted meta-analysis and concluded that cyclophosphamide (CYC) treatment does not induce a statistically significant improvement in lung function in systemic sclerosis (SSc) interstitial lung disease (ILD). This meta-analysis pooled the data from three randomised controlled trials (RCTs) and six observational studies and focused on the changes in pulmonary functional parameters (forced vital capacity [FVC] and diffusing lung capacity for carbon monoxide [DLCO]) of SSc patients treated with CYC for at least 1 year [1]. Such a conclusion sets a negative scenario in which CYC should not be considered as an 'anchor' drug for the treatment of SSc and ILD.

In SSc, no drug or combination of drugs has been demonstrated to modify disease progression. In both RCTs versus placebo, the trend toward improvement in FVC suggests that the efficacy of CYC on lung function is limited, as also corroborated by a mild effect size (Table 1) [2,3]. This negative opinion may not reflect what is going on in a 'real life' scenario, when other efficacy parameters are considered.
Actually, the scleroderma lung study group reported, after 12 months, a significant reduction of Mahler's dyspnea index in CYC-treated patients when compared with placebo $(P<0.0001)$ and a statistically significant amelioration of short form-36 (SF-36) in each domain: mental $(P=0.006)$, emotional $(P=0.005)$, general health status $(P=0.003)$, and vitality $(P=0.009)[4]$. Despite the negligible value of effect size for all of these scale domains, minimum clinically important difference (which represents the smallest improvement in the score of a health-related quality of life measurement instrument which patients perceive as beneficial) was significantly higher for all measures in CYC-treated patients [5]. The improvement of dyspnea and reduction of skin thickness may have a favourable effect not only on functional status but also on psychological aspects, as demonstrated by the analysis of each SF-36 domain.

In SSc, the efficacy of CYC is an important issue and therefore attention needs to be focused on some clinical facts that are observed in 'real life' in everyday practice. The first fact is that, when ILD is treated in an advanced phase, no drug has been able to 'clean' the lung, reverting fibrosis into a normal parenchyma. Actually, in most studies carried out in patients with long-lasting disease, CYC has been able to 'freeze' the disease process. For a disease such as SSc, in which 'everything (or nothing) seems to work' [6], this may be considered a positive result that should encourage physicians to move the use of CYC to the earliest phase of SSc, before fibrosis does consistent damage in the interstitial compartment. The second fact is that the identification of early pulmonary disease remains a problem because the tools used so far may be inadequate. On high-resolution computed tomography, a ground-glass appearance of lower lobes can reflect the presence of a thin yet irreversible fibrosis [7].

$\mathrm{CYC}=$ cyclophosphamide; DLCO = diffusing lung capacity for carbon monoxide; FVC = forced vital capacity; ILD = interstitial lung disease; $Q A L Y=$ quality-adjusted life year; RCT = randomised controlled trial; SF-36 = short form-36; SSc $=$ systemic sclerosis. 
Table 1

Primary and secondary outcomes in three randomised controlled trials and corresponding effect sizes

\begin{tabular}{|c|c|c|c|}
\hline Reference & Outcomes & Effect size & Safety \\
\hline \multirow[t]{2}{*}{$\begin{array}{l}\text { 1. Hoyles, et al. [3], } \\
2006\end{array}$} & $\begin{array}{l}\text { Follow-up after } 1 \text { year } \\
\text { Primary endpoints: } \\
\text { FVC: no change } P=0.08 \text { versus placebo } \\
\text { DLCO: no change } P=0.64 \text { versus placebo } \\
\text { TLC: no change } P=0.61 \\
\text { FEV1: no change } P=0.16 \\
\text { Kco: no change }\end{array}$ & $\begin{array}{l}E S=0.35(\mathrm{Cl}-0.24,0.94) \\
E S=-0.01(\mathrm{Cl}-0.59,0.58) \\
E S=0.06(\mathrm{Cl}-0.53,0.64) \\
E S=0.28(\mathrm{Cl}-0.31,0.86) \\
E S=0.3(\mathrm{Cl}-0.29,0.88)\end{array}$ & $\begin{array}{l}3 \text { withdrawals in the active group due } \\
\text { to side effects ( } 1 \text { patient had } \\
\text { intolerable nausea and } 1 \text { patient had } \\
\text { abnormal findings on liver function } \\
\text { tests during treatment with AZA) and } \\
\text { no withdrawals in the placebo group } \\
\text { (NNH=11) }\end{array}$ \\
\hline & $\begin{array}{l}\text { Secondary endpoint: } \\
\text { HRCT: trends toward to improve } P=0.39\end{array}$ & $\mathrm{NNT}=5$ & \\
\hline \multirow[t]{2}{*}{$\begin{array}{l}\text { 2. Tashkin, et al. [2], } \\
2006\end{array}$} & $\begin{array}{l}\text { Skin score: decreased } \\
\text { Diffuse } \\
\text { Limited } \\
\text { Primary outcome: } \\
\text { FVC: increased }(\mathrm{P}<0.03) \text { favouring Cyc }\end{array}$ & $\begin{array}{l}E S=-0.24(\mathrm{Cl} 0.09,-0.56) \\
E S=-0.06(\mathrm{Cl} 0.27,-0.38) \\
E S=-0.04(\mathrm{Cl} 0.28,-0.37)\end{array}$ & $\begin{array}{l}20 \text { patients withdrew in the active } \\
\text { group and } 13 \text { patients in the placebo } \\
\text { group, mostly due to adverse events } \\
\text { or serious adverse events within } \\
12 \text { months. } \\
\text { (NNH=11.2) }\end{array}$ \\
\hline & $\begin{array}{l}\text { Secondary outcomes: } \\
\text { TLC: increased }(P=0.026) \text { favouring Cyc } \\
\text { DLCO: no change } \\
\text { SF-36 score: } \\
\text { Physical: no change versus placebo } \\
\text { Mental: no change versus placebo } \\
\text { HAQ-DI: decreased } \\
\text { Transitional dyspnea score: improvement } \\
\quad P<0.001\end{array}$ & $\begin{array}{l}E S=0.19(\mathrm{Cl}-0.13,0.52) \\
E S=-0.06(\mathrm{Cl}-0.38,0.27) \\
E S=0.24(\mathrm{Cl}-0.09,0.56) \\
E S=0.27(\mathrm{Cl}-0.06,0.6) \\
E S=-0.37(\mathrm{Cl}-0.04,-0.69) \\
\text { Not possible to calculate }\end{array}$ & \\
\hline \multirow[t]{4}{*}{$\begin{array}{l}\text { 3. Nadashkevich, } \\
\text { et al. [11], } 2006\end{array}$} & $\begin{array}{l}\text { MRSS: decreased after } 12(P<0.001) \\
\text { and } 18 \text { months }(P<0.01) \text { of therapy in } \\
\text { Cyc group versus baseline; } P<0.001 \\
\text { versus controlled patients }\end{array}$ & $\begin{array}{l}E S=-1.31(\mathrm{Cl}-0.74,-1.85) \\
\text { after } 6 \text { months } \\
E S=-5.94(\mathrm{Cl}-4.7,-7.03) \\
\text { after } 12 \text { months } \\
E S=-9.21(\mathrm{Cl}-7.39,-10.79) \\
\text { after } 18 \text { months }\end{array}$ & $\begin{array}{l}\text { No withdrawals } \\
\text { Adverse events on Cyc included hair } \\
\text { loss, nausea, dyspepsia, and } \\
\text { leucopenia. }\end{array}$ \\
\hline & $\begin{array}{l}\text { Attack frequency of Raynaud: decreased } \\
\text { after } 12(P<0.001) \text { and } 18 \text { months } \\
(P<0.01) \text { of therapy in Cyc group versus } \\
\text { baseline; } P<0.001 \text { versus controlled } \\
\text { patients }\end{array}$ & $\begin{array}{l}\mathrm{ES}=-1.99(\mathrm{Cl}-1.34,-2.58) \\
\text { after } 6 \text { months } \\
\mathrm{ES}=-8.35(\mathrm{Cl}-6.69,-9.81) \\
\text { after } 12 \text { months } \\
\mathrm{ES}=-11.68(\mathrm{Cl}-9.41,-13.66) \\
\text { after } 18 \text { months NNT }=1.3\end{array}$ & \\
\hline & $\begin{array}{l}\text { FVC: no change in Cyc group }(P=\mathrm{NS}) \text {, } \\
\text { worsening in AZA group }(P<0.01) \text { after } \\
6,12 \text {, and } 18 \text { months of therapy versus } \\
\text { baseline; } P<0.001 \text { versus controlled } \\
\text { patients }\end{array}$ & $\begin{array}{l}\mathrm{ES}=3.38(\mathrm{Cl} 2.56,4.12) \\
\text { after } 6 \text { months } \\
\mathrm{ES}=4.92(\mathrm{Cl} 3.85,5.86) \\
\text { after } 12 \text { months } \\
\mathrm{ES}=7.38(\mathrm{Cl} 5.89,8.68) \\
\text { after } 18 \text { months }\end{array}$ & \\
\hline & $\begin{array}{l}D L C O \text { : no change in Cyc group }(P=\mathrm{NS}) \text {, } \\
\text { worsening in AZA group }(P<0.01) \text { after } \\
6,12 \text {, and } 18 \text { months of change in Cyc } \\
\text { group }(P=\mathrm{NS}) \text {, worsening in AZA group } \\
(P<0.001) \text { after } 12 \text { and } 18 \text { months of } \\
\text { therapy versus baseline; } P<0.001 \text { versus } \\
\text { controlled patients }\end{array}$ & $\begin{array}{l}\mathrm{ES}=2.46(\mathrm{Cl} 1.76,3.1) \\
\text { after } 6 \text { months } \\
\mathrm{ES}=5.12(\mathrm{Cl} 4.02,6.09) \\
\text { after } 12 \text { months } \\
\mathrm{ES}=7.72(\mathrm{Cl} 6.16,9.07) \\
\text { after } 18 \text { months }\end{array}$ & \\
\hline
\end{tabular}

AZA, azathioprine; $\mathrm{Cl}$, confidence interval; Cyc, cyclophosphamide; DLCO, diffusing lung capacity for carbon monoxide; ES, effect size; FEV1, forced expiratory volume in 1 second; FVC, forced vital capacity; HAQ-DI, Health Assessment Questionnaire-Disability Index; HRCT, highresolution computed tomography; Kco, monoxide transfer coefficient; MRSS, modified Rodnan skin score; NNH, number needed to harm; NNT, number needed to treat; NS, not significant; SF-36, short form-36; TLC, total lung capacity.

Moreover, neither bronchoalveolar lavage findings nor their changes after CYC treatment may predict the response to
CYC [8]. In this condition, the best available way to identify active and reversible disease seems to be the identification of 
patients in whom a recent decrease of more than $10 \%$ in FVC and/or DLCO has occurred either with or without the development of new symptoms, mainly dyspnoea on exertion. The third fact is that the studies have focused their attention on diffuse SSc patients only, whereas limited SSc patients with ILD are not usually targeted in trials.

Besides efficacy, there is still concern about the use of CYC for the occurrence of adverse events. In fact, according to the scleroderma lung study group, basing the analysis on a case with a history of SSc ILD of 1.5 years, the treatment-related toxicity seems to be higher than the beneficial effect. However, when the authors performed a sensitive analysis that also considered a treatment initiation after 0.7 and 3 years from the diagnosis, they demonstrated that an early initiation of the treatment was associated with a greater preservation of lung function and that it allowed a gain of 0.20 qualityadjusted life years (QALYs) versus a loss of 0.21 QALYs of the case base (disease duration of 1.5 years) and 0.44 QALYs if started after 3 years from the diagnosis [9]. These data clearly demonstrate that an early diagnosis of ILD in SSc is fundamental for starting a treatment that may ameliorate quality of life and increase survival.

We know that the gold standard to assess the efficacy of a drug is an RCT and therefore the only way to lift the curtain on the role of CYC in ILD will derive from a trial on patients with properly defined early and active SSc. The absence of guidelines derived from RCT leaves the treatment in the hands of physicians who almost bare-handedly are still confronted with the challenge of blocking the evolution of SSc and of ILD [10]. The increasing awareness and knowledge of SSc pathogenesis, the development of international networks (European League Against Rheumatism Scleroderma Trials And Research [EUSTAR] group), and the fact that new promising drugs (mycophenolate and kinase inhibitors) and treatment strategies (hematopoietic stem cell transplantation) are now under scrutiny in RCTs indicate that we are just at the dawn of a new era that likely will lead to the identification of therapies able to consistently slow the eventual evolution of SSc to fibrosis and atrophy.

\section{Competing interests}

The authors declare that they have no competing interests.

\section{References}

1. Nannini C, West CP, Erwin PJ, Matteson EL: Effects of cyclophosphamide on pulmonary function in patients with scleroderma and interstitial lung disease: a systematic review and meta-analysis of randomized controlled trials and observational prospective cohort studies. Arthritis Res Ther 2008, 10:R124.

2. Tashkin DP, Elashoff R, Clements PJ, Goldin J, Roth MD, Furst DE, Arriola E, Silver R, Strange C, Bolster M, Seibold JR, Riley DJ, Hsu VM, Varga J, Schraufnagel DE, Theodore A, Simms R, Wise $R$, Wigley F, White B, Steen V, Read C, Mayes M, Parsley E, Mubarak K, Connolly MK, Golden J, Olman M, Fessler B, Rothfield $\mathrm{N}$, et al.: Cyclophosphamide versus placebo in scleroderma lung disease. $N$ Engl J Med 2006, 354:2655-2666.
3. Hoyles RK, Ellis RW, Wellsbury J, Lees B, Newlands P, Goh NS, Roberts C, Desai S, Herrick AL, McHugh NJ, Foley NM, Pearson SB, Emery P, Veale DJ, Denton CP, Wells AU, Black CM, du Bois RM: A multicenter, prospective, randomized, double-blind, placebo-controlled trial of corticosteroids and intravenous cyclophosphamide followed by oral azathioprine for the treatment of pulmonary fibrosis in scleroderma. Arthritis Rheum 2006, 54:3962-3970.

4. Tashkin DP, Elashoff R, Clements PJ, Goldin J, Roth MD, Furst DE, Silver RM, Goldin J, Arriola E, Strange C, Bolster MB, Seibold JR, Riley DJ, Hsu VM, Varga J, Schraufnagel D, Theodore A, Simms R, Wise R, Wigley F, White B, Steen V, Read C, Mayes M, Parsley E, Mubarak K, Connolly MK, Golden J, Olman M, Fessler $B$, et al:: Effects of 1-year treatment with cyclophosphamide on outcomes at 2 years in scleroderma lung disease. $A m ~ J$ Respir Crit Care Med 2007, 176:1026-1034.

5. Khanna D, Yan X, Tashkin DP, Furst DE, Elashoff R, Roth MD, Silver R, Strange C, Bolster M, Seibold JR, Riley DJ, Hsu VM, Varga J, Schraufnagel DE, Theodore A, Simms R, Wise R, Wigley F, White B, Steen V, Read C, Mayes M, Parsley E, Mubarak K, Connolly MK, Golden J, Olman M, Fessler B, Rothfield N, Metersky $\mathrm{M}$, et al.: Impact of oral cyclophosphamide on healthrelated quality of life in patients with active scleroderma lung disease: results from the scleroderma lung study. Arthritis Rheum 2007, 56:1676-1684.

6. Furst DE, Clements PJ, Wong WK, Mayes MD, Wigley F, White $B$, Weisman M, Barr W, Moreland L, Martin R, Medsger TA Jr. Steen V, Collier D, Weinstein A, Lally E, Varga J, Weiner SR, Andrews B, Abeles M, Peter JB, Seibold JR: Effects of the American College of Rheumatology systemic sclerosis trial guidelines on the nature of systemic sclerosis patients entering a clinical trial. Rheumatology 2001, 40:615-622.

7. Wells AU: High-resolution computed tomography and scleroderma lung disease. Rheumatology (Oxford) 2008, 47 Suppl 5:v59-61.

8. Mittoo S, Wigley FM, Wise R, Xiao H, Hummers L: Persistence of abnormal bronchoalveolar lavage findings after cyclophosphamide treatment in scleroderma patients with interstitial lung disease. Arthritis Rheum 2007, 56:4195-4202.

9. Khanna D, Furst DE, Clements PJ, Tashkin DP, Eckman MH: Oral cyclophosphamide for active scleroderma lung disease: a decision analysis. Med Decis Making 2008, 28:926-937.

10. Miniati I, Conforti ML, Guiducci S, Matucci Cerinic M: David against Goliath: may we target and defeat interstitial lung disease in systemic sclerosis? Clin Exp Rheumatol 2007, 25:169-171.

11. Nadashkevich $\mathrm{O}$, Davis $\mathrm{P}$, Fritzler M, Kovalenko W: A randomized unblinded trial of cyclophosphamide versus azathioprine in the treatment of systemic sclerosis. Clin Rheumatol 2006, 25:205-212. 